\title{
Modelling and Assessment of Radionuclides Differential Transport in Groundwater
}

\author{
Maria de Lurdes Dinis, António Fiúza \\ Geo-Environment and Resources Research Center (CIGAR), Mining Department, \\ Engineering Faculty, University of Porto, Rua Dr. Roberto Frias, 4200-465, Porto, \\ Portugal, mldinis@fe.up.pt; afiuza@fe.up.pt.
}

\begin{abstract}
An overview of the essential features of groundwater transport of radioactive contaminants in a saturated porous media is presented and used in an integrated bi-dimensional phenomenological model of transport and fate. The conception and the assumptions implicit in the model are described. The output results are then compared with values estimated by different mathematical space interpolation techniques applied to experimental sample measurements obtained in the surroundings of a contaminated site. These interpolation methods allowed evaluating the spatial variability of the contamination, defining the contour of the plume. These values are then compared to those produced by the transport and fate model. This methodology was applied to uranium and radium, due to their special environmental concern.
\end{abstract}

\section{INTRODUCTION}

Groundwater is an important pathway for transport of radioactive contaminations in the subsoil. But this type of contamination is difficult to sample and monitor, requiring great dependence on models to predict the fate and transport as well as the variation of concentration along this pathway.

The contaminated groundwater may be considered a potentially significant exposure pathway if the radionuclide concentration in the groundwater exceeds the legal levels, or if the contamination at a particular site could eventually provoke the radionuclide concentrations in groundwater to exceed trigger values. If the concentrations of radionuclides in the groundwater downflow from the site, or in leachate at the site, exceed these values, and the groundwater in the vicinity of the site has the potential to be used as a source of drinking water, it is likely that 
groundwater modelling will be useful, if not necessary; it is also an unavoidable support tool for the eventual decision of site remediation.

An important step in groundwater modelling is identifying the type and approximate quantities of the radionuclides present. This will not only determine the potential offsite impact, but it will also help to identify the magnitude of the risks to potential exposed receptors, the radionuclides mobility and the time period over which the radionuclides may be hazardous. The types of radionuclides will also determine whether radioactive decay and the ingrowth of radioactive daughters are important parameters that will need to be modelled. On the other hand, the ability to reliably predict the rate and direction of the groundwater flow and contamination transport has a critical role in planning and implementing groundwater remediation. This paper presents an overview of the essential components of groundwater water flow and contaminant transport modelling in saturated porous media. It is described the methodology used in groundwater modelling flow, the results of different mathematical interpolation techniques and software tools used to evaluate the spatial variability of radionuclides and define the underground contamination plume.

A contaminated site from a former uranium mine was taken as a case study. To evaluate the level of contamination in the site and in its vicinity, the radionuclides of the U-chain, in particular for uranium and radium concentration, were monitored in the groundwater of the site. Data from sampling points including holes and wells were used to assess the extension of radium and uranium contamination in groundwater.

\section{Methods and Results}

Radionuclides leach from the tailings, move downward through the unsaturated zone to the water table, and then migrate in the saturated ground water system. Usually, these calculations are broken down into three linked sub-pathways: (i) leaching of contaminants from the tailings, (ii) vertical movement of the dissolved contaminant downward to the water table through the unsaturated zone, and (iii) migration of the contaminant in saturated ground water to the receptor point.

We developed a previous model for simulating the radionuclides release from a uranium tailings pile and its migration process through the soil to the groundwater that is already published (Dinis and Fiúza 2005). We will present here the methodology developed to estimate the necessary parameters for modelling groundwater flow.

The release concentration of a radionuclide depends upon characteristics of both the waste and the site. In particular, for solid-waste disposal sites, a very important feature in radionuclides transport is the distribution of the nuclides between the aqueous and the solid phase. The distribution is characterized by the $K_{d}$ parameter, which expresses the fraction of an element in solid form relatively to the fraction in soluble form. The following equation estimates the leachate concentration under equilibrium partitioning conditions (Dinis and Fiúza 2005). 


$$
\mathrm{C}_{\mathrm{L}}=\mathrm{M} /\left(\mathrm{A} \cdot \mathrm{d} \cdot \mathrm{D}+\mathrm{f} \cdot \mathrm{K}_{\mathrm{d}}\right)
$$

In the above equation, $\mathrm{C}_{\mathrm{L}}\left(\mathrm{Bq} / \mathrm{m}^{3}\right)$ is the leachate concentration; $\mathrm{M}(\mathrm{Bq})$ is the amount of radionuclide in the source $(\mathrm{Bq})$; $\mathrm{A}$ is the area of the source $\left(\mathrm{m}^{2}\right) ; \theta(\mathrm{di}$ mensionless) is the volumetric water content, which depends on saturation ratio $\left(\mathrm{R}_{\mathrm{sat}}\right) ; \rho\left(\mathrm{g} / \mathrm{cm}^{3}\right)$ is the bulk density and $\mathrm{K}_{\mathrm{d}}\left(\mathrm{cm}^{3} / \mathrm{g}\right)$ is the distribution coefficient.

Under saturation conditions the saturation ratio is equal to unity $\left(\mathrm{R}_{\mathrm{sat}}=1\right)$ and for unsaturated conditions it is a function of the infiltration rate $\mathrm{I}(\mathrm{m} / \mathrm{yr})$, the saturated hydraulic conductivity, $\mathrm{K}_{\mathrm{sat}}(\mathrm{m} / \mathrm{yr})$, and also of the texture of the soil given by a soil-specific exponential parameter $\mathrm{b}$ (dimensionless). The saturation ratio can be estimated using the following equation (EPA 1996):

$$
\mathrm{R}_{\mathrm{sat}}=\left(\mathrm{I} / \mathrm{K}_{\mathrm{sat}}\right)\left(\frac{1}{2 \cdot \mathrm{b}+1}\right)
$$

\section{The Radionuclides Transport}

Radionuclides may be transported through the unsaturated zone before reaching the saturated zone. Nevertheless, the contamination may also enter directly into the saturated zone.

In the unsaturated zone, the flux moves predominantly downward until it reaches the water table. A simple approach is used to estimate the flux transport time through the unsaturated zone. The water velocity for transport through the unsaturated zone, $\mathrm{V}_{\mathrm{v}}(\mathrm{m} / \mathrm{yr})$, may be estimated by the average infiltration rate, I $(\mathrm{m} / \mathrm{yr})$ :

$$
\mathrm{V}_{\mathrm{v}}=\mathrm{I} / \mathrm{d}
$$

This parameter, $\mathrm{I}(\mathrm{m} / \mathrm{yr})$, is given mathematically by a water balance equation based on the mass conservation law and is estimated as a function of the precipitation rate, $\mathrm{P}_{\mathrm{r}}(\mathrm{m} / \mathrm{yr})$, irrigation rate, $\mathrm{I}_{\mathrm{r}}(\mathrm{m} / \mathrm{yr})$, runoff $(\mathrm{Cr})$ and evapotranspiration $\left(\mathrm{C}_{\mathrm{e}}\right)$ coefficients:

$$
\mathrm{I}=\left(1-\mathrm{C}_{\mathrm{e}}\right) \cdot\left[\left(1-\mathrm{C}_{\mathrm{r}}\right) \cdot \mathrm{P}_{\mathrm{r}}+\mathrm{I}_{\mathrm{r}}\right]
$$

Under saturated conditions, Darcyôs law may be used to describe the volumetric flow of water through a porous medium. Radionuclide velocity transport estimative is based on water seepage velocity: for the contaminants that flow with water, contaminant velocity is the same as water velocity (vertical and horizontal). Groundwater seepage velocity may be calculated by the Darcyôs velocity, V $(\mathrm{m} / \mathrm{yr})$, and by the soil effective porosity $\left(\varepsilon_{\mathrm{e}}\right)$ :

$$
\mathrm{V}_{\mathrm{pw}}=\mathrm{V} / \mathrm{U}_{\mathrm{e}}
$$

Dissolved radionuclides may be transported at velocities lower or equal than the flow velocity of the aquifer due to sorption process. The retardation factor, $\mathrm{R}$ (dimensionless), is used to estimate the time that it takes to transport the radionuclides to a defined distance and can be estimated by the expression: 


$$
\mathrm{R}=1+\left(\mathrm{f} / \mathrm{U}_{\mathrm{e}}\right) \cdot \mathrm{K}_{\mathrm{d}}
$$

Transport and fate of radionuclides in groundwater follows the theoretical approach of the transport processes represented by the basic diffusion/dispersionadvection equation. For the case of unidirectional saturated advective transport of a single dissolved substance with three-dimensional dispersion in an isotropic homogeneous aquifer, the differential equation for solute transport can be approximated as follows (EPA 1996):

$$
\frac{\partial \mathrm{C}}{\partial \mathrm{t}}+\frac{\mathrm{V}_{\mathrm{pw}}}{\mathrm{R}} \cdot \frac{\partial \mathrm{C}}{\partial \mathrm{x}}=\frac{\mathrm{D}_{\mathrm{x}}}{\mathrm{R}} \cdot \frac{\partial^{2} \mathrm{C}}{\partial \mathrm{x}^{2}}+\frac{\mathrm{D}_{\mathrm{y}}}{\mathrm{R}} \cdot \frac{\partial^{2} \mathrm{C}}{\partial \mathrm{y}^{2}}+\frac{\mathrm{D}_{\mathrm{z}}}{\mathrm{R}} \cdot \frac{\partial^{2} \mathrm{C}}{\partial \mathrm{z}^{2}}-\partial \mathrm{C}
$$

In this equation $C\left(B q / \mathrm{m}^{3}\right)$ is the concentration in the liquid phase; $D_{x}, D_{y}, D_{z}$ $\left(\mathrm{m}^{2} / \mathrm{yr}\right)$ are the dispersivities in the $\mathrm{x}, \mathrm{y}, \mathrm{z}$ directions, respectively; $\lambda\left(\mathrm{yr}^{-1}\right)$ is the radioactive decay constant and $\mathrm{V}_{\mathrm{px}}(\mathrm{m} / \mathrm{yr})$ is the $\mathrm{x}$ component groundwater pore velocity. This expression may be solved by Greenô functions to estimate the concentration in the aquifer at some point downgradient of the release where is located the exposition point or the water supply well (EPA 1996).

For a horizontal source of length $\mathrm{L}$ and width $\mathrm{W}$ centred at $(0,0,0)$ in an aquifer of constant depth $b$, as shown in figure 1 , the solution for the generic equation becomes (EPA 1996):

$$
\mathrm{C}=\left(\mathrm{M}_{0}\right) /\left(\mathrm{U}_{\mathrm{e}} \cdot \mathrm{R}\right) \cdot[\mathrm{X}(\mathrm{x}, \mathrm{t}) \cdot \mathrm{Y}(\mathrm{x}, \mathrm{t}) \cdot \mathrm{Z}(\mathrm{x}, \mathrm{t})]
$$

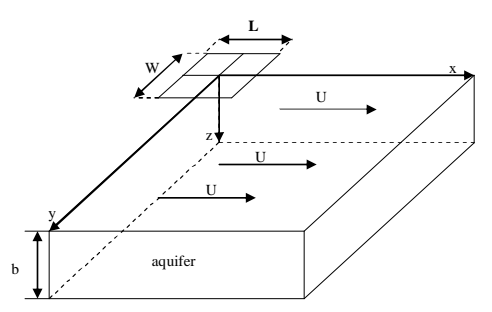

Fig.1. Groundwater dispersion model (EPA 1996).

The release to the aquifer is given by $\mathrm{M}_{0}(\mathrm{~Bq})$ and $\mathrm{X}, \mathrm{Y}, \mathrm{Z}$ are the Greenô functions in the $\mathrm{x}, \mathrm{y}, \mathrm{z}$ coordinate directions, respectively. The Greenôs functions for the boundary conditions defined may be expressed by the following equations (EPA 1996):

$$
X=\frac{1}{2 \cdot L}\left(\operatorname{erf}\left(\frac{(W+L / 2)-\frac{V_{p w}}{R}}{\sqrt{4 \cdot D_{x} \cdot t / R}}\right)+\operatorname{erf}\left(\frac{(W-L / 2)-\frac{V_{p w}}{R}}{\sqrt{4 \cdot D_{x} \cdot t / R}}\right)\right) \cdot e^{(-\partial t)}
$$




$$
Y=\frac{1}{2 \cdot W}\left(\operatorname{erf} \frac{(L / 2+y)}{\sqrt{4 \cdot D_{y} \cdot \frac{t}{R}}}+\operatorname{erf} \frac{(W / 2-y)}{\sqrt{4 \cdot D_{y} \cdot \frac{t}{R}}}\right)
$$

The elapsed time is represented by $\mathrm{t}(\mathrm{yr})$ and ñerfò is the error function.

\section{Case Study}

A contaminated site from a former uranium mine was taken as a case study; the Urgeiriça site located in the central Portugal, near Nelas (Viseu). The mine is surrounded by small farms and country houses, with most of the local population living in the village Canas de Senhorim within about 2-km of the mine.

The mineôs exploitation began in 1913 for radium extraction. The activity of the Urgeiriça mine was maintained until 1945 , then exclusively dedicated to the production of radium. In 1951, a chemical treatment unit for the production of low-grade $\mathrm{U}_{3} \mathrm{O}_{8}$ concentrates was built and in 1967 it was transformed into a modern unit with the capacity to treat about 150 ton of ore per day (Bettencourt et al. 1990). Later, it was enlarged to a capacity of 300 ton/day and after to $600 \mathrm{t} / \mathrm{day}$. In 1991 classical mining explorations ended, but the facilities were still used until 2000 for the treatment of liquors produced by heap leaching of marginal ores from small mines in the surroundings as well as groundwater from the Urgeiriça Mine, previously exploited by in-situ leaching. During almost a century, the total uranium concentrate $\left(\mathrm{U}_{3} \mathrm{O}_{8}\right)$ production reached about 4730 ton, in addition to the radium salts, produced until 1945 .

The extensive treatment of uranium ores at the Urgeiriça processing plant has led to the production of large amounts of solid wastes (tailings) which were deposited into dams in open-air areas. A prominent tailing pile is located near the mine (Fig. 2) occupying an area of 13,3 ha with an esti mated volume of $1390000 \pm 40$ $000 \mathrm{~m}^{3}$ (Pereira et al. 2004).

The tailings are composed mainly of sand and silt particles that were transported as a pulp to the site from the solid-liquid separation by $\mathrm{CCD}^{1}$, after being submitted to grinding and acid leaching. This waste material includes most of the radioisotopes of the uranium decay chains as well as other hazardous chemical elements resulting from the treatment process.

Rain water may infiltrate through the surface of the tailings, interacting with sludge materials and acid producing minerals, becoming strongly acid; eventually these acidic solutions may dissolve and transport radionuclides leading to the groundwater contamination.

\footnotetext{
${ }^{1}$ CCD ï Counter Current Decantation
} 


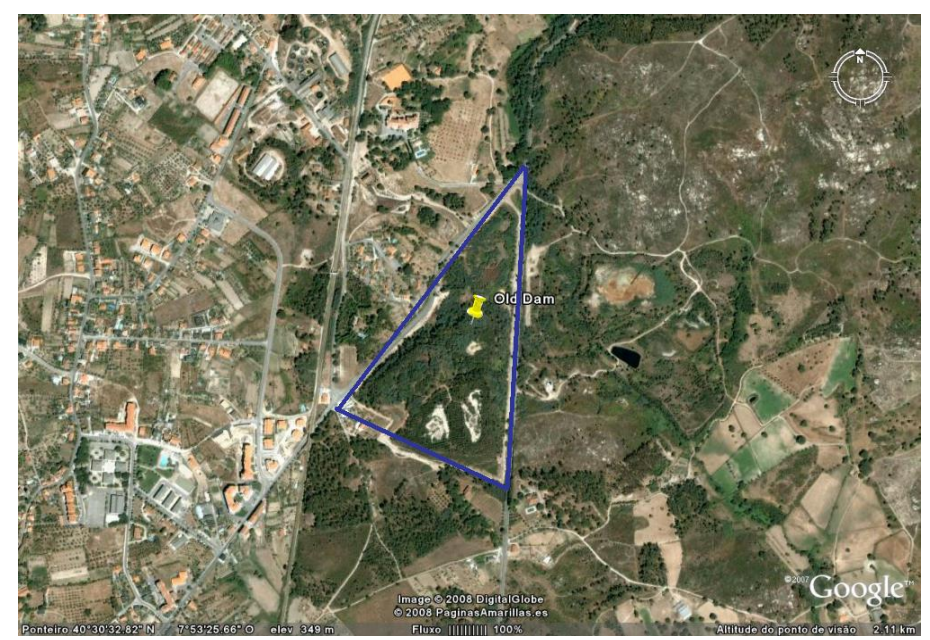

Fig.2. Aerial photo of Urgeiriça site. The village of Canas de Senhorim is located at the upper left corner of the tailings pile identified as BV ï Barragem Velha (Old Dam) (Google Earth).

Using this model, a simulation was done for a release rate of radionuclides $\left(\mathrm{M}_{0}\right.$ in $\mathrm{Bq}$ ) to an aquifer with a constant thickness of $3 \mathrm{~m}$, originated by an horizontal contaminated source of length $425 \mathrm{~m}$ and width $625 \mathrm{~m}$, centred at a point source with coordinates $(212.5,312.5,0)$.

The necessary parameters were adopted from different sources: some resulted from data collected in the Urgeiriça tailings piles (Exmin 2003), others from data given previously by the National Uranium Company (ENU) and also from published data (Bettencourt et al. 1990; Pereira et al. 2004). The unknown parameters were estimated from available data.

Data concerning meteorological parameters, namely precipitation and evaporation were used for estimating the infiltrating water rate into the contaminated zone. The precipitation and evaporation data refers to the Caldas da Felgueira meteorological station (located at about $3 \mathrm{~km}$ to SE of the tailings pile).

A total area of approximately $133000 \mathrm{~m}^{2}$ was considered for the contaminated site. The radionuclide concentration was considered homogenous and equal in all the contaminated area: an average value for each radionuclide concentration was used. Specific hydrogeologic parameters were considered for each zone where the radionuclides transport occurs, namely for the contaminated tailings, for the unsaturated zone and for the saturated groundwater zone; this means that we used different densities, porosities, hydraulic conductivities, distribution coefficients and thicknesses. An hypothetical well water supply is considered to be located at the downgradient edge of the contaminated zone.

Sampled measurements on uranium and radium activity in groundwater from the Urgeiriça site were used for comparison with the model results. 
The analytical values show somehow similar values with those produced by the model. The average value for total uranium in the water at the location of the hypothetical well was about $1,6 \mathrm{~Bq} / \mathrm{L}$ and for radium was about $0,4 \mathrm{~Bq} / \mathrm{L}$. According to the output of the simulation these values are achieved within the first 30 years after the aquifer became contaminated. These results correspond to an effective dose of $0,053 \mathrm{mSv} / \mathrm{yr}$ for ${ }^{238} \mathrm{U}$ and of $0,082 \mathrm{mSv} / \mathrm{yr}$ for ${ }^{226} \mathrm{Ra}$, considering an annual ingestion rate of $730 \mathrm{~L}$ and an effective dose coefficient of $4,5 \times 10^{-5} \mathrm{mSv} / \mathrm{Bq}$ and $2,8 \times 10^{-4} \mathrm{mSv} / \mathrm{Bq}$ for ${ }^{238} \mathrm{U}$ and for ${ }^{226} \mathrm{Ra}$, respectively.

Two sampling campaigns were done at this site by Exmin (2003). The main goal was to evaluate potential seasonal variations in the chemical composition of the groundwater from the contaminated site and surroundings.

The water samples were collected in wells (66) and holes (26) in two different periods, June and November of 2001 (Exmin 2003). Only some of these sampling points were considered for this study, according to their higher probability of being contaminated. One of the criteria for the selection of the samples was the relation between its location and the source; samples collected upstream and to higher distances from the contaminated source have a lower probability of being contaminated by the past mine activities (Pereira et al. 2004b).

In figure 3 are represented the sample points location for wells $\left(\mathrm{P}_{17}, \mathrm{P}_{18}, \mathrm{P}_{19}\right.$, $\mathrm{P}_{20}, \mathrm{P}_{21}, \mathrm{P}_{31}, \mathrm{P}_{32}$ and $\left.\mathrm{P}_{35}\right)$, holes $\left(\mathrm{F}_{3}, \mathrm{~F}_{4}, \mathrm{~F}_{5}, \mathrm{~F}_{6}, \mathrm{~F}_{7}, \mathrm{~F}_{8}\right.$ and $\left.\mathrm{F}_{9}\right)$ and piezometers $\left(\mathrm{S}_{1}\right.$, $\mathrm{S}_{2}, \mathrm{~S}_{3}, \mathrm{~S}_{4}, \mathrm{~S}_{5}, \mathrm{~S}_{6}, \mathrm{~S}_{7}, \mathrm{~S}_{8}, \mathrm{~S}_{9}$ and $\mathrm{S}_{10}$ ). Data from 26 different points were analyzed for chemical and radiological parameters, namely for uranium and radium.

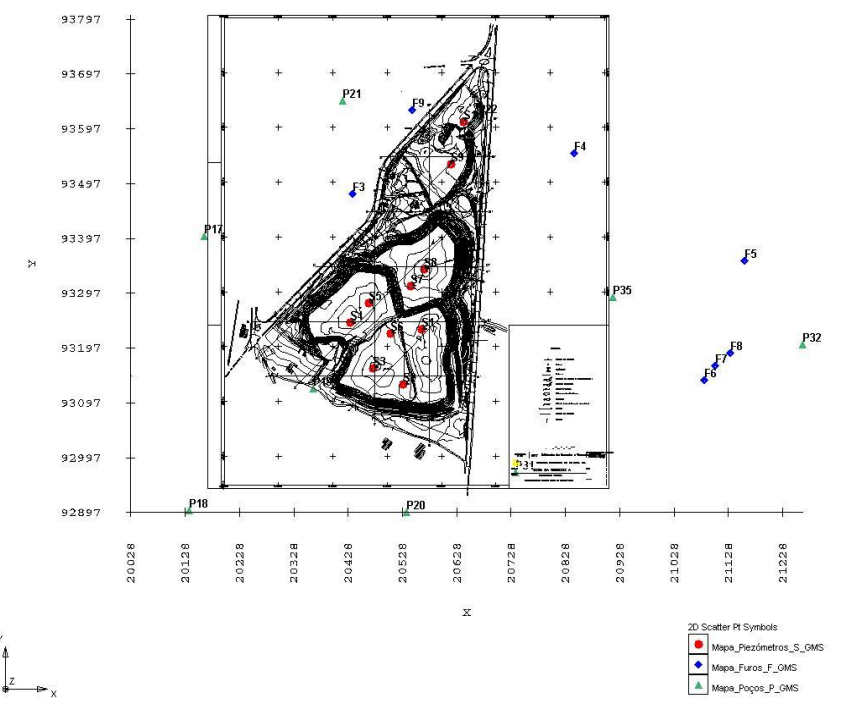

Fig.3. Location of the water samples collected at Urgeiriça uranium mining site. 
Table 1 shows a summary for the basic statistic parameters of uranium and radium concentration in groundwater for all the sampled points.

Table 1. Summary statistic data analysis (wells, holes and piezometers water samples).

\begin{tabular}{lll}
\hline Parameters & $\mathrm{U}(\mathrm{Bq} / \mathrm{L})$ & $\mathrm{Ra}(\mathrm{Bq} / \mathrm{L})$ \\
\hline $\mathrm{N}$ - number of water samples & 26 & 26 \\
\hline$\mu$ - average & 2,835 & 0,284 \\
\hline Median & 0,204 & 0,137 \\
\hline Variance & 36,310 & 0,120 \\
\hline$\sigma / \mu$ & 2,126 & 1,238 \\
\hline Minimum & 0 & 0 \\
\hline Maximum & 28,73 & 1,47 \\
\hline
\end{tabular}

A simple observation of this table shows that the uranium concentration is significantly high, presenting as maximum $28,73(\mathrm{~Bq} / \mathrm{L})$ and although the average value for radium is not severe $(0,284 \mathrm{~Bq} / \mathrm{L})$, the maximum value is significantly high $(1,47 \mathrm{~Bq} / \mathrm{L})$. However, and in particular for uranium, the analytical values showed a high variability for concentration (20 to $30 \%$ ) depending on the season in which the water samples were collected.

With the purpose to analyze the preferential direction of the contaminated samples, which have the presence of mining activities, a geostatistic study was performed for radium and uranium content in the selected water samples.

Different software were used: GMS (Groundwater Modelling System) and Surfer. Also different interpolation techniques were used in GMS software, including directional variogram analysis. This software has a powerful suite of interpolation tools in a two-dimensional geostatistic.

The following interpolation techniques were used from GMS software: linear interpolation (simple linear interpolation based on a triangulation of the scatter points); inverse distance weighted interpolation (includes constant, gradient, plane and quadratic nodal functions); clough-tocher interpolation (piece-wise cubic patch approach adapted from finite element method); natural neighbour interpolation (technique based on natural neighbours computed from Thiessen polygons) and kriging (ordinary and universal kriging routines with graphical variogram editing).

For the kriging interpolation technique the Surfer software was used as it has a better adjust and realist representation. A variogram analysis was also performed.

The following figures represent the results of these different interpolation methods. Only the most representative are presented here. 


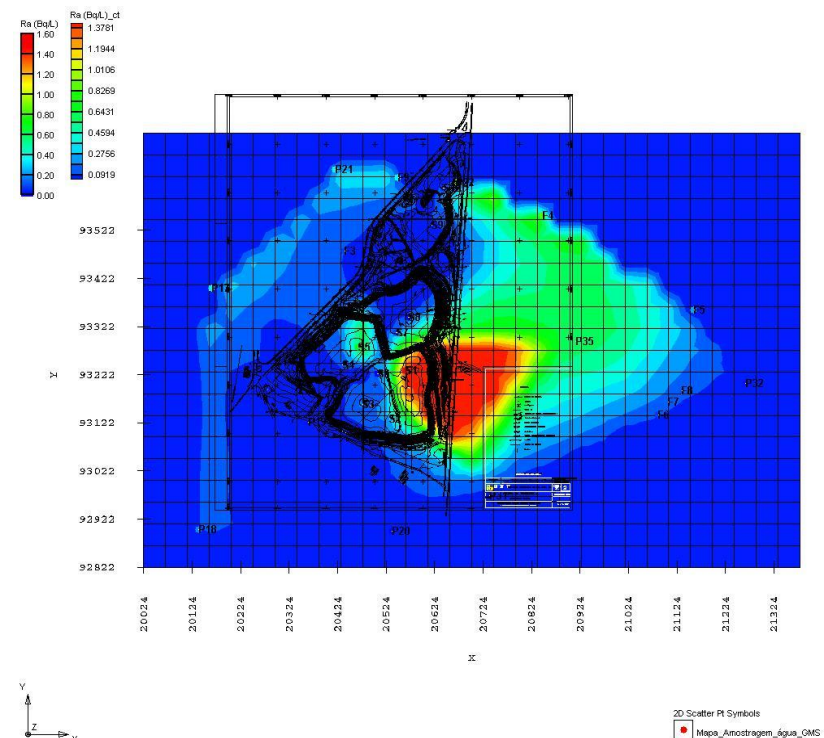

Fig.4. Clough-tocher interpolation (cubic triangular), $\mathrm{Ra}(\mathrm{Bq} / \mathrm{L})$.

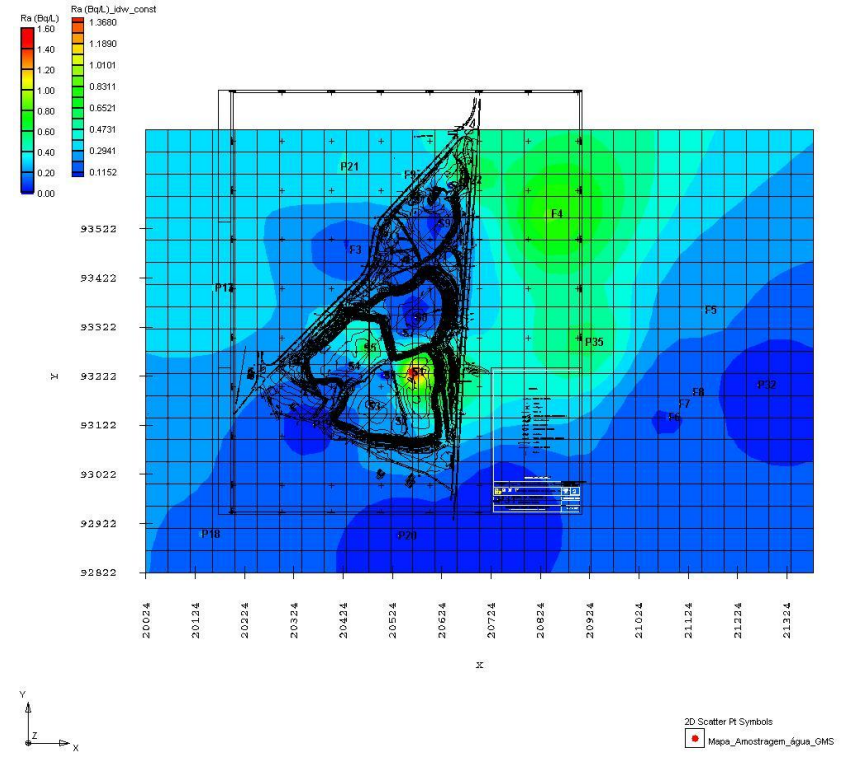

Fig.5. Inverse distance weighted interpolation (constant function), $\mathrm{Ra}(\mathrm{Bq} / \mathrm{L})$. 


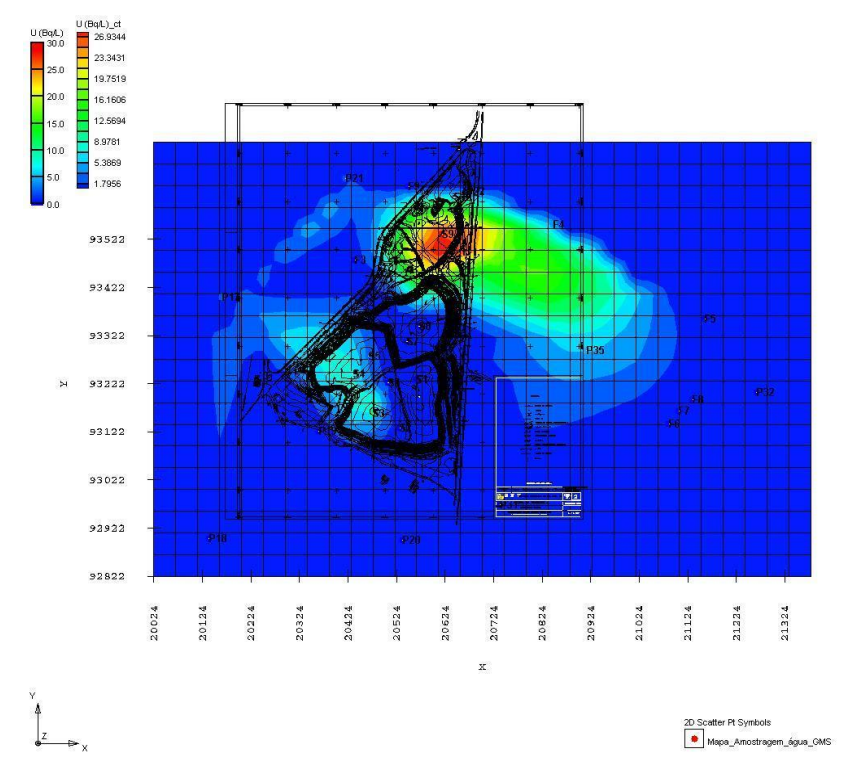

Fig.6. Clough-tocher interpolation (cubic triangular), U (Bq/L).

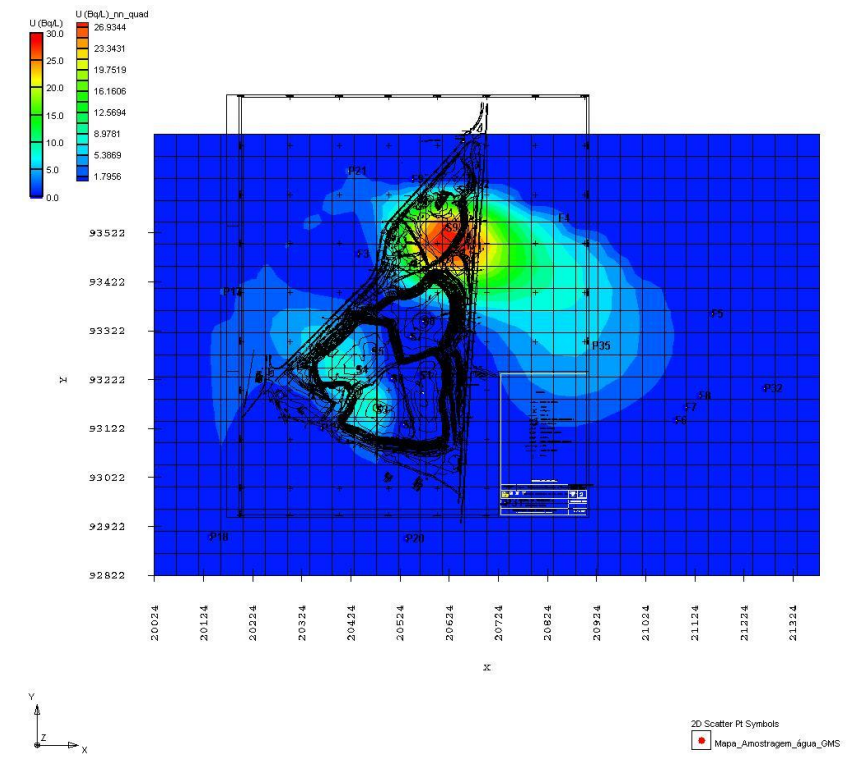

Fig.7. ñNatural neighborò interpolation (quadratic function), $\mathrm{U}(\mathrm{Bq} / \mathrm{L})$. 


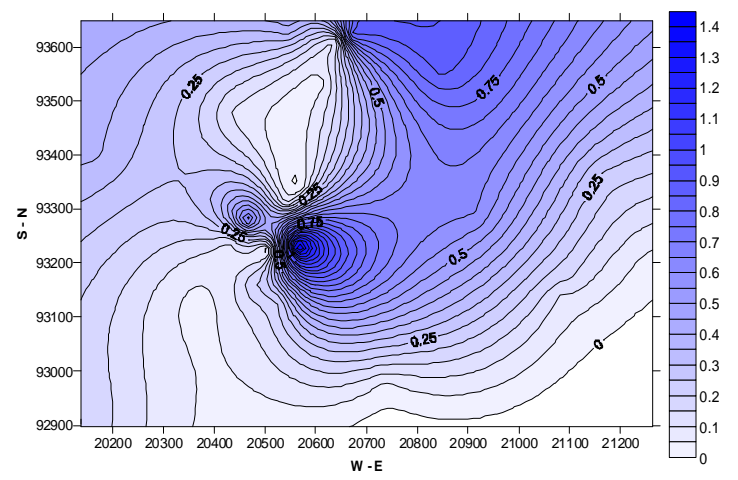

Fig.8. Dispersion of Ra contamination in groundwater $(\mathrm{Bq} / \mathrm{L})$ represented by kriging.

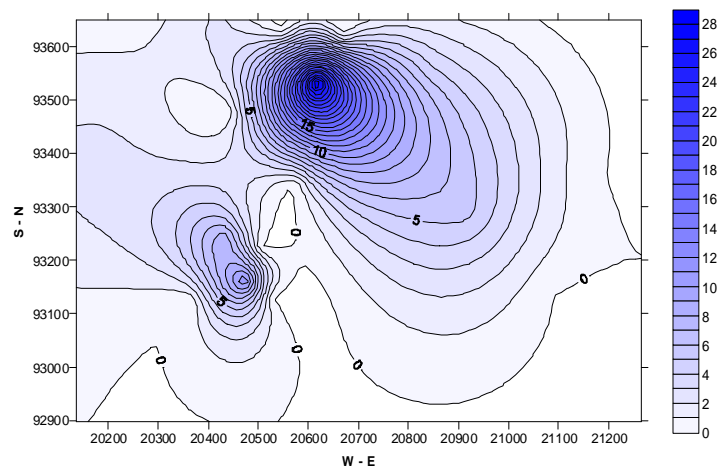

Fig.9. Dispersion of $\mathrm{U}$ contamination in groundwater $(\mathrm{Bq} / \mathrm{L})$ represented by kriging.

\section{Conclusions}

A previous model for radionuclides transport and fate in groundwater, based on a one-dimensional analytical solution, has been developed and already published (Dinis and Fiúza 2005). The results obtained in this study by applying Greenôs functions are in good accordance with those obtained with the previous model: the medium value for total uranium in the well water was about $1,6 \mathrm{~Bq} / \mathrm{L}$ and for radium about $0,4 \mathrm{~Bq} / \mathrm{L}$. These values are achieved in the previous model within the first 30 years after the aquifer contamination and with the Greenôs functions method these values were also achieved within the same period of time.

Also it should be noted that the maximum values for both nuclides are higher than the standard values acceptable for radionuclides in groundwater at inactive uranium mill tailings site; the USEPA has established the Maximum Contaminant Level (MCL) for combined ${ }^{226} \mathrm{Ra}$ and ${ }^{228} \mathrm{Ra}$ of $0,185 \mathrm{~Bq} / \mathrm{L}$. The European Union 
has also issued a Directive on the quality of drinking water, including regulations for radioactive substances. The EU Directive allows a Maximum Permissible Level (MPL) for ${ }^{226} \mathrm{Ra}$ of $0,122 \mathrm{~Bq} / \mathrm{L}$. This MPL was exceeded in $56 \%$ of the water samples analysed.

The estimative dose resulting from the two radionuclides considered was 0,135 $\mathrm{mSv} / \mathrm{yr}$. The recommended reference level of committed effective dose is $0,1 \mathrm{mSv}$ from 1 year's consumption of drinking water.

The high radionuclides content registered for underground waters indicates that the site has been contaminated by the former mine works. Considering radionuclides dispersion through groundwater system, it was observed that there are two preferential plume contamination directions, whether uranium or radium is considered. These two directions suggest that SW-NE direction is preferential to radium dispersion and that NW-SE direction is preferential to uranium dispersion. This allowed us to identify two preferential contamination targets: at south for radium and at north for uranium.

The results obtained both by the groundwater pathway model and by the dispersion techniques assessment led to the forecast of unacceptable concentrations; this results should be taken into account in the management guidelines included in the design of the remediation process. These management guidelines should be based on factors such as efficiency of contamination reduction, legal requirements and physical constraints that are stressed in this study.

\section{References}

Bettencourt A.O., Teixeira M.M., Elias M.D., Madruga M.J. (1990), Environmental Monitoring in Uranium Areas. In: Environmental Behaviour of Radium, Vol. 2. Technical Reports Series N. ${ }^{\circ} 310$, pp. 281-294, IAEA, Vienna.

Dinis M.L., Fiúza A. (2005), Simulation of Liberation and Transport of Radium from Uranium Tailings, in: Uranium in the Environment - Mining Impact and Consequences, pp. 609-618. Broder J. Merkel; Andrea Hasche-Berger (Eds), 897 pp., Springer publishers - ISBN 10 3-540-28363-3; ISBN 13 978-3-540-28368-8.

EPA U. S. Environmental Protection Agency (1996), Documenting Ground-Water Modeling at Sites Contaminated with Radioactive Substances, U. S. Environmental Protection Agency, EPA 540-R-96-003, PB96-963302.

EXMIN (2003), Estudo Director de Áreas de Minérios Radioactivos ï 2. a fase, Companhia de Indústria e Serviços Mineiros e Ambientais, SA.

Pereira A.J.S.C., Dias J.M.M., Neves L.J.P.F., Nero J.M.G. (2004), Modelling Efficiency of a Rehabilitation Plan for a Uranium Mill Tailing Deposit (Urgeiriça, Central Portugal). XI International Congress of the Radiation Protection Association, Madrid, Spain, 23-28 May.

Pereira, A.J.S.C, Neves L.J.P.F., Dias J.M.M., Campos A.B.A., Barbosa, S.V.T. (2004b), Evaluation of the Radiological Hazards from Uranium Mining and Milling Wastes (Urgeiriça Ï Central Portugal), XI International Congress of the International Radiation Protection Association. 